\title{
Legal Education: Globalization, and Institutional Excellence: Challenges for the Rule of Law and Access to Justice in India
}

\author{
C. Raj Kumar \\ Jindal Global Law School, crk@jgu.edu.in
}

Follow this and additional works at: https://www.repository.law.indiana.edu/ijgls

Part of the Comparative and Foreign Law Commons, International Law Commons, Legal Education Commons, and the Legal Profession Commons

\section{Recommended Citation}

Kumar, C. Raj (2013) "Legal Education: Globalization, and Institutional Excellence: Challenges for the Rule of Law and Access to Justice in India," Indiana Journal of Global Legal Studies: Vol. 20 : Iss. 1 , Article 8. Available at: https://www.repository.law.indiana.edu/ijgls/vol20/iss1/8

This Symposium is brought to you for free and open access by the Law School Journals at Digital Repository @ Maurer Law. It has been accepted for inclusion in Indiana Journal of Global Legal Studies by an authorized editor of Digital Repository @ Maurer Law. For more information, please contact rvaughan@indiana.edu.

\section{$\Psi$}

JEROME HALL LAW LIBRARY

INDIANA UNIVERSITY

Maurer School of Law
Bloomineton 


\title{
Legal Education, Globalization, and Institutional Excellence: Challenges for the Rule of Law and Access to Justice in India
}

\author{
C. RAJ KUMAR*
}

\begin{abstract}
Legal education plays an important role in developing lawyers who act as social engineers and work towards the cause of nation building. In a globalized world, law schools face the challenges of increased foreign competition and reduction of the role of the state. At the same time, globalization affords space for re-examining higher education systems by affording opportunity for establishing global universities with international collaborations and programs. This article examines the role of law schools in India and proposes reforms in Indian legal education system in the light of globalization. It examines how the private sector in India can contribute to imparting legal education in public service. Keeping in tune with the developments brought about by globalization, the article proposes setting up global universities with global curricula, faculty, and programs. This article also examines the challenges before the Indian legal education system, including the need to develop good infrastructure, the difficulties in hiring good quality faculty and attracting young lawyers to a career in academia, the lack of research initiatives within Indian law schools, and the lack of academic freedom available to faculty members. The article addresses how a global university can overcome these challenges, creating an environment that promotes teaching, learning, and researching in a manner that inspires future lawyers to work toward establishing a rule of law society in India.
\end{abstract}

* LL.B. (Delhi), B.C.L. (Oxford), LL.M. (Harvard), S.J.D. (Hong Kong); Vice Chancellor, O.P. Jindal Global University; Dean, Jindal Global Law School; Member, National Legal Knowledge Council; Email: crk@jgu.edu.in, vc@jgu.edu.in Web: www.jgu.edu.in. I would like to acknowledge that parts of this article have been drawn from my previous articles published in The Hindu as well as other newspapers and magazines published in India. I would like to thank Professor Jayanth Krishnan for his valuable comments on an earlier version of this article. I appreciate the help and assistance of my Research Associate, Ms. Raadhika Gupta.

Indiana Journal of Global Legal Studies Vol. 20, Issue 1 (2013)

(C) Indiana University Maurer School of Law 


\section{INTRODUCTION}

Globalization and the changing dimensions of the Indian economy and polity have resulted in new challenges for governance. Rule of law in all its dimensions remains the single most important challenge the country is facing. The criminal and civil justice systems are under severe stress. The role of law schools in imparting legal education and developing lawyers who are rational thinkers and social engineers is central to the future of legal education and the development of a knowledge economy in India. ${ }^{1}$ This can be done only if the law schools are able to attract some of the best and the brightest lawyers to make a lifelong commitment to teaching, learning, and researching so that they are able to inspire generations of students to work toward establishing a rule of law society in India.

Globalization has been a subject of debates and discussions from numerous perspectives. ${ }^{2}$ There is no doubt that globalization has profound implications for the future of higher education worldwide. While the debate relating to foreign universities coming into India or private investment in higher education is very important, it is critical to

1. A number of articles have been written on the importance of bringing reforms in legal education to make it more socially relevant, and the various ways in which this can be done. See, e.g., Thomas S. Ulen, The Impending Train Wreck in Current Legal Education: How We Might Teach Law as the Scientific Study of Social Governance, 6 U. St. Thomas L.J. 302 (2009); Praveen Kosuri, Losing My Religion: The Place of Social Justice in Clinical Legal Education, 32 B.C. J.L. \& SoC. JUST. 331 (2012); Frank S. Bloch \& M. R. K. Prasad, Institutionalizing a Social Justice Mission for Clinical Legal Education: Cross-National Currents From India and the United States, 13 CLINICAL L. REV. 165 (2006).

2. See, e.g., Swethaa Ballakrishnen, Homeward Bound: What Does a Global Legal Education Offer the Indian Returnees?, 80 FORDHAM L. REV. 2441 (2012) (arguing that Indian students with American LL.M. degrees who return to India do not always benefit from the credential); Simon Chesterman, The Evolution of Legal Education: Internationalization, Transnationalization, Globalization, 10 GERMAN L.J. 877 (2009) (analyzing the impact of globalization on legal education worldwide); Jayanth $\mathrm{K}$. Krishnan, Peel-Off Lawyers: Legal Professionals in India's Corporate Law Firm Sector, 9 SOCIO-LEGAL REV. (forthcoming 2013); Luca C. M. Melchionna, Global Legal Education and Comparative Visa Regulations, 19 Transnat'L L. \& ConTEMP. ProBs. 515 (2010) (analyzing some features of the globalization process of U.S. legal education and how U.S. law schools are dealing with regulations of foreign jurisdictions in order to expand overseas); Mihaela Papa \& David B. Wilkins, Globalization, Lawyers, and India: Toward a Theoretical Synthesis of Globalization Studies and the Sociology of the Legal Profession, 18 INT'L J. LEGAL PROF. 175 (2011) (studying the interactions among economic globalization, globalization of knowledge, and globalization of governance to analyze the Indian legal profession); Carole Silver, The Variable Value of U.S. Legal Education in the Global Legal Services Market, 24 GEo. J. LEGAL ETHICS 1 (2011) (studying the impact of U.S. LL.M. degrees pursued by foreign law graduates in the creation of "global lawyers" for the current global legal services market). 
examine how India as a country will face the competition posed by institutions worldwide in attracting Indian students for educational opportunities abroad. Inevitably, the need for raising academic standards, creating a better research environment, developing sound infrastructure, formulating good governance models, creating better career opportunities, and promoting professional advancement of academics are all central issues for formulating the necessary policies for higher education.

\section{Challenges of Reform in Higher Education IN INDia}

Globalization has changed the dynamics of polity and society. "Since the development of a knowledge economy remains an important goal of both developed and developing countries, the establishment of educational institutions of global excellence ought to become the priority of the developing countries." 3 India has yet to achieve these priorities. ${ }^{4}$ While the National Knowledge Commission has been making a number of useful and important recommendations that deserve serious and urgent attention, ${ }^{5}$ there is still a gap between the rhetoric of reform and the reality of governance. This problem is acutely felt in the education sector. ${ }^{6}$ There is stiff resistance within the government to seek fundamental reforms that would enable a favorable regulatory environment. ${ }^{7}$

3. ANIl Kumar Thakur \& Mohan Patel, Challenges of Education in the 21ST CENTURY 345 (2010).

4. For some of the challenges to higher education in India, see Shyam Sunder, Higher Education Reforms in India (Yale School of Management, Working Paper Dec. 7, 2011), available at http://ssrn.com/abstract $=1975844$.

5. See, e.g., NAT'L KNOWLEDGE COMM'N, GOV'T OF INDIA, REPORT TO THE NATION 80-81 (Nat'l Knowledge Comm'n, 2009), available at http://www.knowledgecommission.gov.in/ downloads/report2009/eng/report09.pdf. The National Knowledge Commission was constituted in 2005 as an advisory body to the Indian Prime Minister with the objective of transforming India into a knowledge society by enabling easy access to knowledge, creating and preserving knowledge systems, disseminating knowledge and better knowledge services. It submits recommendations to guide policy and direct reforms on various areas including education, science and technology, agriculture, industry, and e-governance.

6. See Education Needs a Reality Check: Nigavekar Dona, THE TIMES OF INDIA (July 1, 2011), http://articles.timesofindia.indiatimes.com/2011-07-01/education/29725472_1_ higher-education-reforms-education-sector-indian-education.

7. See Both Academics and Politicians Must Cooperate for Urgently Needed Higher Education Reforms, THE TIMES OF INDIA (Nov. 15, 2012), http://articles.timesofindia.indiatimes.com/2012-11-15/edit-page/35111160_1_highereducation-academics-resistance. 


\section{A. Private Actors and Public Service}

Privatization in higher education does not necessarily imply the evolution of greater competition among institutions leading to higher academic standards. ${ }^{8}$ Indian private players have not embraced the notion of public service as the basic framework for promoting education. ${ }^{9}$ Their notion of promoting public service is connected to the notions of philanthropy and corporate social responsibility-all of which are in the nascent stage of development in India. ${ }^{10}$ Education in the private sphere is largely a mediocre commercial activity that needs radical reforms. ${ }^{11}$ While globalization has created new opportunities for promoting growth and development in education, the focus of this growth ought to be based on the principles of public service that are essential for achieving reforms in education. It is notable that most of the reputed universities in the United States are the products of private players with a common motto: "A private university in the public service."12

The future of higher education in India is hugely dependent on the role of the private sector and to what extent the regulatory policies in higher education favor the role of this sector. ${ }^{13}$ The N.R. Narayana Murthy Committee on Corporate Sector Participation in Higher Education also recommended an increase in the role of the private sector in higher education in India. ${ }^{14}$ It further recommended that higher education institutions should have "complete financial, academic and administrative autonomy." 15 Arun Nigavekar, the former chairman

8. See generally John V. Lombardi, Introductory Remarks: Reflections on Privatization in Higher Education, 10 U. FLA. J.L. \& PUB. POL'Y 1 (1998) (discussing the issues presented by privatizing aspects of higher education).

9. C. Raj Kumar, Why Are We Lagging Behind?, DigitalLEARning (Sept. 11, 2012), http:/digitallearning.eletsonline.com/2012/09/why-are-we-lagging-behind/.

10. Kailash Chandra Das, Imbibing Public Libraries and Corporate Social Responsibility to Promote Rural Development, 33 DESIDOC J. LIBR. \& INFO. TECH. 11, 11 (2013).

11. Kumar, supra note 9.

12. For example, New York University proudly declares its motto: "A Private University in the Public Service." 175 Facts About NYU, N.Y.U., http://www.nyu.edu/ library/bobst/research/arch/175/pages/motto2.htm (last visited Apr. 3, 2012).

13. See C. Jayanthi, Private Sector Needed in Higher Education, THE HINDU Business LINE (Feb. 23, 2012) (India), http://www.thehindubusinessline.com/opinion/ article2924685.ece.

14. Murthy Panel for Greater Put Sector Role in Higher Education, BUSINESS STANDARD (May 9, 2012), http://bsl.business-standard.com/india/news/murthy-panel-forgreater-pvt-sector-role-in-higher-education $/ 473826 /$.

15. The Corporate View, THE HINDU (May 28, 2012), http://www.thehindu.com/todayspaper/tp-features/tp-educationplus/article3463341.ece?css=print. 
of the University Grants Commission, lamenting on the poor state of higher education in India, also advocated for greater autonomy for colleges. ${ }^{16}$ The Indian higher education sector requires government support and trust for the establishment of autonomous private universities that provide good quality education to students. It is necessary to recognize that governments in developing countries like India are not in a position to wholly support significant levels of financial commitments needed to establish and sustain reputed institutions of higher learning. ${ }^{17}$ In this context, it is important that the role of the private sector be appreciated and expanded. ${ }^{18}$ But the expansion of this role ought to be based on the commitment of private universities and centers of learning to promote excellence in education. The stellar achievement of the Indian School of Business in Hyderabad of becoming one of the top twenty business schools of the world, ${ }^{19}$ within a decade, is an inspiring achievement for promoting world-class institutions of higher learning in the private domain. ${ }^{20}$

\section{B. A Global University}

Universities worldwide are preparing themselves to face the challenges of globalization. Some of the most reputed universities in the world are gearing up to promote internationalization in education. ${ }^{21}$ The internationalization of universities has transcended geographical barriers and universities all over the world have made it a priority to devote time and attention and to commit resources to becoming "global" universities. ${ }^{22}$ In the Indian context, there is much to be done to develop

16. Education Needs a Reality Check: Nigavekar Dona, supra note 6.

17. Kian Ganz, Funding Crunch Looms Over Indian Law Schools, LIVEMINT, Apr. 26, 2012 (India), http://www.livemint.com/2012/04/26202957/Funding-crunch-looms-overIndi.html.

18. See Jandhyala B. G. Tilak, Higher Education Policy in India in Transition, 47(13) ECONOMIC AND POLITICAL WEEKLY 36, 40 (2012) (India).

19. Indian School of Business figures twelfth in the Financial Times 2010 Rankings of Global MBA Institutes. See Global MBA Rankings 2010, FT.COM, http://rankings.ft.com/businessschoolrankings/global-mba-rankings-2010 (last visited Apr. $3,2012)$.

20. See generally Sanat Kaul, Higher Education in India: Seizing the Opportunity (Indian Council for Research on Int'l Econ. Relations, Working Paper No. 179, 2006), available at http://www.icrier.org/pdf/WP_179.pdf (discussing growth of knowledge sector in India).

21. See Chesterman, supra note 2, at 884-85; Richard Levin, Universities Branch Out, $\begin{array}{llcc}\text { NEWSWEEK (Aug. } & \text { 21-28, 2006), } & \text { available } \\ \text { http://www.law.yale.edu/documents/pdf/public_affairs/presidentlevinarticle.pdf. }\end{array}$

22. See Anthony Bradney, Raising the Drawbridge: Defending University Law Schools, WEB J. CURRENT LEGAL ISSUES 1995, available at http://webjcli.ncl.ac.uk/articles1/ 
the concept of a global university and to promote internationalization in higher education at existing institutions. In this regard, the functioning of the existing regulatory bodies needs to be carefully examined so that the country is better prepared to encourage the establishment of many global universities.

The president of Yale University, Professor Richard Levin, speaking at Jawaharlal Nehru University in 2005, said:

The globalization of the university is in part an evolutionary development. . . . But creating the global university is also a revolutionary developmentsignaling distinct changes in the substance of teaching and research, the demographic characteristics of students and scholars, the scope and breadth of external collaborations, and the engagement of the university with new audiences. When I speak of becoming a global university, I envision a curriculum and a research agenda permeated by awareness that political, economic, social, and cultural phenomena in any part of the world can no longer be fully understood in isolation. ${ }^{23}$

In August 2006, Newsweek magazine ranked the top 100 global universities, taking "into account openness and diversity, as well as distinction in research." 24 The list included Harvard, Stanford, and Yale, in that order. Cambridge, Oxford, MIT, and Columbia were among the top ten global universities. ${ }^{25}$ There was not a single university from South Asia among the top 100 , while even a smaller city like Hong Kong had three universities on the list. ${ }^{26}$ The methodology used to rank the global universities included the criteria adopted by the well-known rankings published by Shanghai Jiaotong University and the Times of London Higher Education Survey: the number of highly cited researchers in various academic fields, the number of articles published in Nature and Science, the number of articles listed in the Institute for

bradneyl.html (discussing the need for law universities to be cautious of their "increasingly international character").

23. Richard C. Levin, President, Yale Univ., The Global University: Inauguration of the Fox International Fellowships, Speech at Jawarharlal Nehru University (January 2, 2005), available at http:/communications.yale.edu/president/speeches/2005/01/02/globaluniversity-inauguration-fox-international-fellowships.

24. The Top 100 Global Universities, MSNBC.COM (August 13, 2006), http://web.archive.org/web/20060820193615/msnbc.msn.com/id/14321230/site/newsweek/ (last visited Apr. 3, 2012).

25. Id.

26. Id. 
Scientific Information (ISI) Social Sciences and Arts \& Humanities indices, the percentage of international faculty, the percentage of international students, citations per faculty member (using ISI data), the ratio of faculty to students, and library holdings (using number of volumes). ${ }^{27}$ The Times Higher Education World University Rankings 2012-2013 do not feature even a single Indian university in the top 200 universities of the world, even though there was a rise of Asian universities in a significant manner, with China (2), Taiwan (2), Hong Kong (4), Japan (5), Singapore (2), and the Republic of Korea (4) prominently figuring in the list. ${ }^{28}$ These rankings assess the universities on the basis of the following criteria: teaching (30 percent); research (30 percent); citations ( 30 percent); international outlook ( 7.5 percent); and industry income (2.5 percent). ${ }^{29}$ Similarly, no Indian university figures among the top 200 universities of the world as per the QS World University Rankings 2012. ${ }^{30}$ The weight of the six indicators used for these rankings are as follows: academic reputation (40 percent); citation per faculty (20 percent); faculty-student ratio (20 percent); employer reputation (10 percent); international faculty ratio (5 percent); and international student ratio (5 percent). ${ }^{31}$ Academic reputation, which carries the maximum weight, is based on the views of academics around the world with regard to the universities that produce the best research in their field of expertise. ${ }^{32}$

\section{Global Collaboration}

"While developing global universities becomes the central focus of reforms in higher education, there is a need to be innovative in promoting global collaborations and interactions among universities." 33 Indian universities have to carefully consider their policies for establishing global collaborations and activities that promote global interaction. It is not useful to sign numerous Memoranda of

27. Id.

28. World University Rankings 2012-2013, http://www.timeshighereducation.co.uk/worlduniversity-rankings/2012-13/world-ranking (last visited Mar. 11, 2013).

29. The Essential Elements in our World-Leading Formula, (Oct. 4, 2012), http://www.timeshighereducation.co.uk/world-university-rankings/2012-13/world-ranking/ methodology (last visited Mar. 11, 2013).

30. QS World University Rankings-2012, http://www.topuniversities.com/universityrankings/world-university-rankings/2012. (last visited Mar. 11, 2013).

31. QS World University Rankings Methodology, (Sept. 11, 2012), http://www.topuniversities.com/university-rankings-articles/world-university-rankings/qsworld-university-rankings-methodology (last visited Mar. 11, 2013).

32. Id.

33. THAKUR \& PATEL, supra note 3 , at 345 . 
Understanding that do not translate into concrete forms of collaboration among universities leading to implementation of programs for students and scholars. Universities, as a part of their internal governance mechanisms, need to evolve policies that will guide them in establishing collaborations with other institutions. In the context of law, the Legal Education and Research Society (LEARS), a nonprofit institution, helped in implementing a global legal education program in which two distinguished graduates from Yale Law School will spend a whole year teaching in two of the selected law schools in India. ${ }^{34}$ This program is the first of its kind, and such programs need encouragement and expansion. By enabling direct interaction between foreign teachers and Indian students, the program enables a true collaboration that benefits both teachers and students as opposed to collaborations that remain only on paper. While students get the advantage of learning from the knowledge and experience of teachers from the best law schools of the world, the young foreign graduates get useful opportunities to widen their perspectives by interacting with students and faculty from the developing world. It also gives Indian universities an opportunity to learn from new teaching methodologies and consider implementing them for other courses taught at the university. At the same time, foreign graduates can learn from methodologies in place in India and take their useful experiences back to universities in the United States.

\section{Expansion of Scholarship}

The global university agenda in India needs to have the development of scholarship as one of its core missions. Research and scholarship ought to become a priority in universities in India so that creation of knowledge becomes the fundamental objective of higher education. ${ }^{35}$

34. Letter from Harold Hongju Koh, Dean, Yale Law Sch. (Nov. 27, 2007). The program allows fully-funded fellowships for Yale law graduates with an academic bent of mind to spend a whole year teaching at law schools in South Asia. It aims at sending two graduates from Yale Law School, all expenses covered by Yale to any two selected law schools in South Asia, where they teach for one year. The program has been implemented at the National Law School of India University, Bangalore; NALSAR University of Law, Hyderabad; Jindal Global Law School of O.P. Jindal Global University, Haryana; and Lahore University and Management Sciences, Pakistan. Id.

35. See Alya Mishra, New Bill on Innovation Universities to Boost Research,

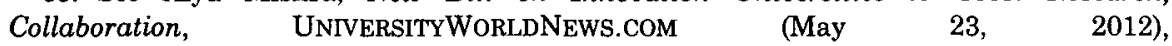
http://www.universityworldnews.com/article.php?story=20120523125757485 (describing a bill introduced by the Indian Parliament to boost research and innovation by Indian universities). 
India is undergoing dramatic transformation. It is important to take steps toward establishing universities that will bring together the best of academic scholarship, teaching excellence, and research aptitude for promoting knowledge-based initiatives all across the country. Establishing global universities of excellence has the potential to create new opportunities for growth and development in the knowledge sector, which is expected to be the key to future expansion of the Indian economy. ${ }^{36}$ The creation, development, and dissemination of knowledge need to be democratized. Democratization can take place only if both the state and private sectors make efforts to develop many global universities that will meet the governance challenges of India and the world at large. ${ }^{37}$ Otherwise put, India needs a number of global universities of excellence that provide a world-class education, promote cutting-edge research across disciplines, and encourage our youth to assume a leadership role in nation building.

\section{REFORMING LEGAL EDUCATION IN INDIA}

The need for promoting excellence in legal education in India ought to be predicated upon our responses to the following central issues relating to the future of legal education in India:

1. Globalization and legal education

2. Excellence in legal education

3. Rule of law and legal education

4. Academic freedom in education

\section{A. Globalization and Legal Education}

Within the larger debate relating to reform of the higher education sector in India, there is an urgent need to examine legal education and the impact globalization will have on it. ${ }^{38}$ There are four important

\footnotetext{
36. See Carl Dahlman \& Anuja Utz, India and the Knowledge Economy: Leveraging Strengths and Opportunities, WORLD BANK INSTITUTE 8-12, http://info.worldbank.org/etools/docs/library/138271/IndiaKEExecutiveSummary\%5B1\%5 D.pdf (last visited January 28, 2013).

37. See generally Laurel S. Terry, Steve Mark, \& Tahlia Gordon, Trends and Challenges in Lawyer Regulation: The Impact of Globalization and Technology, 80 FORDHAM L. REV. 2661 (2012) (discussing the consequences of globalization on the legal profession).

38. See John Varghese, Global Legal Education AND INDIA - A BluEPRINT For RAISING INDIAN LEGAL EDUCATION TO GLOBAL STANDARDS (2010), available at http://papers.ssrn.com/sol3/papers.cfm?abstract_id=1728451 (discussing current state of legal education in India and its changing contours due to globalization).
} 
consequences for legal education: global curriculum, global faculty, global degrees, and global interaction. These deserve attention.

\section{Global Curriculum}

A few decades back, law schools in India could do well as long as their curricula were focused on Indian law and issues relating to the country's legal system. ${ }^{39}$ While there was some limited impetus to the study of international and comparative law, the larger focus was primarily on issues relating to the Indian legal system. ${ }^{40}$ This was, of course, the necessary approach. There is indeed great room for improvement in teaching excellence and research relating to Indian law that can address the challenges facing the legal system, including the need for establishing a society that respects the rule of law and meets the challenges of globalization. ${ }^{41}$ However, new and emerging law schools cannot afford to limit their focus to teaching and research on issues relating to Indian law. In fact, the appetite of Indian law students for understanding international and comparative law has significantly increased over the years, given their participation in international moot court competitions that address issues such as maritime law, humanitarian law, and dispute resolution. ${ }^{42}$ To enable Indian lawyers to compete in the transnational marketplace, law curricula must include topics of universal application and provide education in new areas like comparative law, information technology,

39. Nehaluddin Ahmad, Adapting Indian Legal Education to the Demands of a Globalizing World, 10 GERMAN L.J. 847 (2009).

40. The Bar Council of India has also established a Curriculum Development Committee. For more information see Curriculum Development Committee, BARCOUNCILOFINDIA.ORG, http://www.barcouncilofindia.org/about/legal-education/ curriculum-development-committee/ (last visited Aug. 23, 2012). For a comparative assessment on the development of legal education elsewhere during this time, see Jayanth K. Krishnan, Academic SAILERS: The Ford Foundation and the Efforts to Shape Legal Education in Africa, 1957-1977, 52 Am. J. Legal Hist. 261 (2012).

41. N.R. Madhava Menon, The Future of Law Teaching Institutions, THE HINDU, July 30, 2002, http://www.hindu.com/thehindu/edu/2002/07/30/stories/2002073000100200.htm (India).

42. For example, NALSAR University of Law, Hyderabad won the 2012 world rounds of the Monroe E. Price International Media Law Moot Court Competition conducted by Oxford University, U.K. NALSAR Students Win International Moot Court Competitions, THE HINDU (Apr. 23, 2012), http://www.thehindu.com/education/article3345856.ece (describing the Monroe E. Price International Media Law Moot Court Competition); Ajay Parmar, NLU Jodhpur Students Bring Laurels, TimeS OF INDIA (Apr. 4, 2012), http://articles.timesofindia.indiatimes.com/2012-04-04/jaipur/31286889_1_journal-nlujodhpur-national-law-school (describing the Stetson Environmental Law Moot Court Competition). 
intellectual property, corporate governance, human rights, and international trade law. ${ }^{43}$ "A greater exposure to foreign laws not only will prepare our graduates to practice in an increasingly global environment, but it will also equip them with a deeper understanding of the choices made by [their] own legal system," giving lawyers and judges "more colors on their palates from which to choose in fashioning creative solutions to modern legal problems." 44 The most challenging task is to strike a proper balance to ensure that students are taught a fair mix of courses that gives them knowledge and training in Indian law, but at the same time prepares them for facing the challenges of globalization, whereby domestic legal mechanisms interact with both international and foreign legal systems. This interaction is going to increase in the years to come and our law schools must prepare themselves to face this challenge posed by globalization. ${ }^{45}$

\section{Global Faculty}

Hiring good faculty has been a challenge in law schools in India and abroad.46 Generally, the financial incentives offered to attract good lawyers to an academic career are far more attractive in the private sector, both in India and abroad, than those available in the public sector, including law schools. ${ }^{47}$ But it is possible to attract good lawyers to academia by promoting a range of educational reforms and institutional initiatives, including better financial incentives. ${ }^{48}$ Globalization has indeed provided new opportunities to address some of the challenges in this regard. Issues relating to the Indian legal system are not only taught and researched in India, but also in many other

43. See generally Ahmad, supra note 39, at 847 (discussing and comparing legal curricula in various countries).

44. R. Michael Cassidy, Beyond Practical Skills: Nine Steps for Improving Legal Education Now, 53 B.C. L. REV. 1515, 1522 (2012).

45. See John J. Costonis, Introduction: Global Law and the Law School Curriculum, 52 J. LEGAL EDUC. 1 (2002).

46. See Sunder, supra note 4 (discussing the issue of attracting people to teaching and scholarship as a challenge for Indian higher education).

47. See, e.g., Tamar Lewin, Survey Finds Small Increase in Professors' Pay, N.Y. TIMES, April 11, 2011, http://www.nytimes.com/2011/04/11/education/11faculty.html?; AAUP Releases Faculty Salary Report, AAUP, http://www.aaup.org/AAUP/newsroom/2012PRs/ salarysurvey.htm (last visited January 28, 2013); Slight Increase in Faculty Salaries, NATIONAL EDUCATION ASSOCIATION, http://www.nea.org/home/34399.htm (last visited January 28, 2013).

48. See Jack Grove, Academic Salaries No Longer Attract Top Talent, Survey Finds, Times Higher EduCATION (Mar. 22, 2012), http:/www.timeshighereducation.co.uk/ story. asp?storycode $=419399$. 
parts of the world. ${ }^{49}$ Growing numbers of Indian lawyers and scholars are involved in this effort. ${ }^{50}$ There is need for having a global focus in hiring faculty for Indian law schools. Of course, success will depend on the schools' abilities to provide the right kind of intellectual environment and financial and other incentives for Indian or foreign scholars to teach and pursue research in India and to contribute to its growth story.

\section{Global Programs}

Indian law schools need to consider innovation when it comes to the degree programs they offer. ${ }^{51}$ At present, there are two models in India: the three-year Bachelor of Law (LL.B) program offered by many universities and the five-year integrated BA (Hons)-cum-LL.B program offered by the national law schools, starting with the one in Bangalore.52 It will be useful to look at the experience of the United States and others in examining whether Indian law schools should consider offering the Juris Doctor (J.D.) program. ${ }^{53}$ The starting of the J.D. program in the United States is largely credited to Christopher Columbus Langdell when he was dean of the Harvard Law School from 1870-95, although the University of Chicago was the first law school to offer a J.D. degree. ${ }^{54}$ Increasingly, many parts of the common law world are beginning to offer J.D. programs; law schools in Australia, Canada,

49. For example, courses on comparative constitutional law taught in some American universities include the study of Indian constitutional law. See Course Catalog, HARVARD LAW SCHOOL, http:/www.law.harvard.edu/academics/curriculum/catalog/index.html (last visited Sept. 23, 2012) (listing the Comparative Constitutional Law course); Course Descriptions, THE UNIVERSITY OF MICHIGAN LAW SCHOOL, http:/www.law.umich.edu/ currentstudents/registration/ClassSchedule/Pages/AboutCourse, aspx?crseId=043899 (last visited Sept. 23, 2012) (listing the Global Constitutionalism course).

50. For example, the Indian Society of International Law (ISIL) is a national institution for teaching, research, and promotion of international law and how the application of international law affects India. About ISIL, THE INDIAN SOCIETY OF INTERNATIONAL LAW (ISIL), http://www.isil-aca.org/about_ISIL.htm (last visited Jan. 27, 2013).

51. See, e.g., Jaideep Shenoy, Future Law Labs Will Necessarily Need to Innovate, TIMES OF INDIA (May 29, 2012), http://articles.timesofindia.indiatimes.com/2012-0529/mangalore/31887007_1_law-colleges-kslu-lab.

52. Ahmad, supra note 39.

53. See Jayanth K. Krishnan, Professor Kingfield Goes to Delhi: American Academics, the Ford Foundation, and the Development of Legal Education in India, 4 AM. J. LEGAL HIST. 447, 472 (2004) (explaining the difficulties faced by the Ford Foundation in developing a western legal education system in India).

54. See David Perry, How Did Lawyers Become "Doctors"?, 84 N.Y. ST. B.J. 20, 21 (2012). 
and Hong Kong are at the forefront. ${ }^{55}$ Obviously, there is an emerging trend in favor of J.D. programs. ${ }^{56}$

There could be many sound justifications for offering a J.D. program in India. One of the important reasons for starting an integrated B.A.-LL.B program was to attract some of the brightest high school graduates to the legal profession and to raise the standards of the Bar by providing sound legal education. ${ }^{57}$ This objective was indeed achieved to some extent, but the context and circumstances have changed. Law is increasingly becoming a preferred career not only among high school graduates, but also among students holding other professional degrees. ${ }^{58}$ For example, there is a growing interest among engineers to study law, and this is likely to increase over the years. ${ }^{59}$ There is also a growing interest among students who have pursued a liberal arts undergraduate education in history, sociology, economics, political science, and other disciplines in pursuing legal studies. ${ }^{60}$ Under the existing five-year integrated law program in the national law schools, it will be a long term commitment of eight years for other degree holders to study law, unless they decide to enter one of the three-year LL.B programs offered by many law schools that are part of traditional universities. In this context, it will be useful to examine whether a graduate entry J.D. program can be established in India. It is relevant to note that starting in 2008, Melbourne Law School, one of Australia's

55. Terrence Belford, Why Change to a JD Degree?, GLobecampus, Feb. 25, 2009, http://www.globecampus.ca/in-the-news/globecampusreport/why-change-to-a-jd-degree/; Senate Committee on Academic Development, Proposed Change of Degree Name and Basis of Admission for Undergraduate Degree in Law (LL.B.), http://www.queensu.cal secretariat/senate/agendasminutes/022808/LawDgree.pdf (last visited Jan. 28, 2013).

56. Id.

57. See Vikrant Pachnanda, Special Report, Whether Senior Advocates Pay Too Little To Their Juniors?, INDIA L. J., January-March 2011, available at http://www.indialawjournal.com/volume4/issue_1/special_report.html (noting that the aim of the first national law school was to get "more people [to] join the bar," thus improving the quality of lawyers and judges).

58. J. Venkatesan, Madhava Menon Gets Best Law Teacher Award, THE Hindu, Sept. 5, 2009, http://www.hindu.com/2009/09/05/stories/2009090560281500.htm.

59. Divy Khare, Students Prefer Law over Engineering, THE TIMES OF INDIA, June 4, 2012, http://articles.timesofindia.indiatimes.com/2012-06-04/ranchi/32030866_1_delhipublic-school-dps-nlu.

60. See Priyanka Singh, Legal Benefits: Job Options, Fat Salaries Draw Students to Law, EXPRESSINDIA, June 21, 2012, http://www.expressindia.com/latest-news/legalbenefits-job-options-fat-salaries-draw-students-to-law/636461/. See generally Chandra Krishnamurthy, Legal Education and Legal Profession in India, 36 INT'L J. LEGAL INFo. 245, 253-54 (2008) (suggesting that the desirability of a legal education program for university graduates be considered). 
oldest and most reputed law schools, began to offer only a graduate entry J.D. program and scrapped its LL.B program. ${ }^{61}$

\section{Global Interaction}

The law schools of the future ought to provide academic space for engaging in teaching and cutting edge research on issues of global significance. The institutions ought to constantly reinvent themselves for facing the challenges of globalisation through exchange and collaboration programmes. This has different implications for faculty, students, and for the development of teaching and research programmes. ${ }^{62}$

In this regard, it is important to note that token arrangements of collaboration may not be helpful to the institutions involved. There is a need to develop a shared understanding of the nature of exchange and collaborative programs being established for them to be effective and beneficial for all the parties concerned.63 "Globalisation has posed multiple challenges to the future of legal education in India, but it has provided an opportunity to challenge the status quo, which is an essential condition for seeking any reform." 64

\section{B. Excellence in Legal Education}

Historically, Indian legal education consisted of a three-year undergraduate program within the law departments of universities and resulted in an LL.B degree. ${ }^{65}$ Legal education and its importance in establishing a rule of law society did not receive any serious priority or

\footnotetext{
61. The Melbourne LLB, THE UNIVERSITy OF MELBOURNE, http://undergraduate.law.unimelb.edu.au/ (last updated Sept. 12, 2012).

62. See Lynden Griggs, Comment: The Integration of Teaching and Research in Higher Education, 25 HERDSA NEwS (2005), available at http://www.herdsa.org.au/wpcontent/uploads/2007/06/3_herdsa_news_december_2005.pdf.

63. See generally Elizabeth B. Cooper, Global Collaboration in Law Schools: Lessons to Learn, 30 FORDHAM INT'L L.J. 346 (2006) (using different instances of global collaboration in law schools to illustrate how it can be used to develop programs of legal education as well as further the goal of social justice).

64. Pallavi Mahajan, Changing Nature Of Legal Education Due To Globalization 1 (2011), available

http://papers.ssrn.com/sol3/papers.cfm?abstract_id=1840625\&download=yes.
}

65. Id. at 2 . 
attention in these universities, ${ }^{66}$ although due to the sheer motivation of students themselves the departments were successful in producing many of the brightest lawyers and some of the best academics in the country. University law departments have not made adequate progress in academic standards such as innovation of course design, development of appropriate teaching modules, formulation of research agendas, undertaking of research projects, and promotion of advocacy in lawyering. ${ }^{67}$ These traditional departments also suffered from lack of independence and institutional autonomy, as they were within the university system whose priorities did not always match. ${ }^{68}$ As a result, the ability to attract serious students with a passionate commitment to study law in all its facets dramatically declined, culminating in institutionalized mediocrity in a large number of law faculties across the country. ${ }^{69}$

There is no doubt that the establishment of the national law schools, starting with the National Law School of India University (NLSIU) in Bangalore, successfully challenged this institutionalized mediocrity and succeeded in attracting serious students to the study of law. ${ }^{70}$ In fact, the study of law has received better attention among high school graduates in the country since the introduction of five-year integrated programs. ${ }^{71}$ These programs raise new issues relating to pedagogy and approach to undergraduate studies for imparting legal education for high school graduates. The national law schools established in Bangalore, Hyderabad, Kolkata, Bhopal, and Jodhpur have all, in their own ways, promoted excellence in legal education and research, particularly by attracting some of the brightest students to consider law as a preferred career option. ${ }^{72}$ But these schools still face significant challenges in attracting faculty members who are top researchers in the field of law and who can combine sound teaching methods with established track records of research. ${ }^{73}$ The lack of researchers in the

66. See Krishnamurthy, supra note 60 at $246-47$ (discussing the importance of the rule of law and how the standards of legal education have declined).

67. See, e.g., Ahmad, supra note 39. The lack of adequate progress gives rise to entities that try to improve legal education. E.g., Legal Education, NAT'L KNOWLEDGE COMM'N, http://www.knowledgecommission.gov.in/focus/legal.asp (last visited Aug. 23, 2012).

68. See Krishnamurthy, supra note 60 at 258.

69. C. Raj Kumar, Improving Legal Education in India, THE HINDU, June 27, 2007, http://hindu.com/2007/06/27/stories/2007062750481000.htm.

70. Krishnamurthy, supra note 60 , at 258.

71. See id. at 257-58 (discussing how five-year programs were designed to attract more high school graduates to the study of law).

72. See Seedling School of Law \& Governance, JAIPUR NAT'L U. http://www.jnujaipur.ac.in/schools/index.aspx?sid=16 (last visited Feb. 7, 2013).

73. Prime Minister Dr. Manmohan Singh highlighted this problem in his speech. See Manmohan Singh, Prime Minister of India, Inaugural Address at the Conference of 
legal field and the failure to emphasize research and publication at existing law schools have led to the absence of an intellectually vibrant environment. ${ }^{74}$

Research can contribute significantly to improving teaching and, more importantly, addressing numerous challenges relating to law and justice. ${ }^{75}$ If one were to look at the faculty profile of the world's top law schools, one would find that there is great emphasis on research and publication among academics. ${ }^{76}$ Besides teaching, the faculty contribute in significant ways by initiating and developing research projects in cutting-edge areas; by making professional contributions to international organizations, law firms, and corporations; and by playing an important role in the formulation of government policy and the promotion of civil society activism. ${ }^{77}$

Law schools and academics in India greatly need to develop an institutional culture that promotes and encourages research that has the capacity to foster many positive changes in society at large. The following are some of the hurdles in the way of this development.

\section{Developing Physical Infrastructure and Financial Resources}

Law schools in India have to recognize that there is a need for creating sound physical infrastructure. ${ }^{78}$ There should be more funds for this and for developing research projects and other initiatives to encourage faculty members. Generally, the infrastructure of the twelve national law schools is better than what exists in the law departments

National Consultation for Second Generation Reforms in Legal Education (May 1, 2010) available at $\mathrm{http}: / /$ pmindia.nic.in/speech-details.php?nodeid=889.

74. See Menon, supra note 41.

75. See Lovely Dasgupta, Reforming Indian Legal Education: Linking Research and Teaching, 59 J. LEGAL EDUC. 432, 434-35 (2010) (discussing research as a critical component of the quality of law professors, who, in turn, influence the success of their students as future lawyers and the overall success of the legal educational program).

76. For example, the top law schools in the world as per QS World University Rankings, including Harvard, Yale, Oxford, and Cambridge, have scored five out of five in the category of "research." QS World University Rankings by Subject 2012: Social Sciences \& Management-Law, QS TOPUNIVERSITIES, http://www.topuniversities.com/ university-rankings/world-university-rankings/2012/subject-rankings/social-science/law (last visited Jan. 28, 2013).

77. See generally Benjamin E. Berkman \& Karen H. Rothenberg, Teaching Law Students to be Policymakers: The Health and Science Policy Workshop on Genomic Research, 40 J.L. MED. \& ETHICS 147 (2012) (discussing a workshop created by law professors designed to give law students hands-on experience in the field of health policy, specifically as it relates to the emerging issues in the area of genomic science, and allow them to provide recommendations to policymakers).

78. See NAT'L KNOWLEDGE COMM'N, Gov'T OF INDIA, supra note 5, at 80-81. 
of traditional universities, ${ }^{79}$ but improvement in infrastructure should be across the board, especially in universities that still produce most of the law graduates. University campuses should be places that can inspire students and faculty to reflect upon the various problems that confront society. Academic freedom to think and contribute cannot be ensured if universities lack the necessary physical infrastructure and financial resources. ${ }^{80}$

\section{Developing Philanthropic Initiatives}

Legal education in India by and large remains a state-sponsored endeavour or an unimpressive commercial enterprise devoid of high academic standards. ${ }^{81}$ Philanthropy in legal education is rare. ${ }^{82}$ There is an urgent need for encouraging philanthropic initiatives that promote excellence in legal education and research in the country. ${ }^{83}$ The National Knowledge Commission (NKC), constituted by the Union Government in 2005, recently submitted its first annual report. ${ }^{84}$ Legal education was one of the focus areas; among the different issues considered as part of the NKC's consultations with law academics and practitioners were "methods of attracting and retaining talented faculty" and "developing a serious research tradition that is globally competitive." 85 The NKC report noted the following with regard to philanthropic contributions: "It is clear that we have not exploited this potential. In fact, the proportion of such contributions in total

79. Kumar, supra note 69.

80. See NAT'L KNOWLEDGE COMM'N, Gov'T OF INDIA, supra note 5, at 80 (noting that a good infrastructure is important in order to create a research tradition in law schools).

81. Kumar, supra note 69.

82. Id.

83. See Sunder, supra note 4 , at $18,24-25$ (discussing the role of philanthropic funding in higher education in India).

84. National Knowledge Commission (NKC) was constituted on June 13, 2005 with a timeframe of three years, from October 2, 2005 to October 2, 2008. As a high-level advisory body to the Prime Minister of India, the National Knowledge Commission has been given a mandate to guide policy and direct reforms, focusing on certain key areas such as education, science and technology, agriculture, industry, e-governance, etc. Easy access to knowledge, creation and preservation of knowledge systems, dissemination of knowledge and better knowledge services are core concerns of the NKC. In its endeavor to transform the knowledge landscape of the country, the NKC has submitted around 300 recommendations on 27 focus areas during its three and a half year term. While the term of the NKC has come to an end, the implementation of NKC's recommendations is currently underway at the Central and State levels. NAT'L KNOWLEDGE COMM'N, GoV'T OF INDIA, supra note 5 (providing this information in the report's forward, which is not numbered).

85. See NAT'L KNOWLEDGE COMM'N, supra note 67. 
expenditure on higher education has declined from more than 12 per cent in the 1950s to less than 3 per cent in the 1990s." 86 Philanthropy in legal education is essential for its growth and development. All stakeholders, including the law schools, the Bar, the bench, the law firms, and corporations should make every effort to promote philanthropic initiatives in legal education and research. ${ }^{87}$

\section{Hiring Good Teachers and Researchers}

The present system does not sufficiently recognize the key problem with regard to legal education-lack of faculty members who are good teachers as well as sound researchers. ${ }^{88}$ There is need to identify talent among young lawyers so that they can be encouraged to consider academia as a career option. ${ }^{89}$ There is no doubt that poor financial incentives discourage many young and brilliant lawyers from considering a career in academia. ${ }^{90}$ It is important to address this issue as well. But there could be other areas where improvements and changes are feasible such as development of career opportunities within the law schools; development of research infrastructure, including the resources to organize and participate in national and international conferences and to undertake serious research; creation of a harmonious environment that fosters mutual respect; governance of the law schools in a transparent fashion; and, above all, faith that the leadership of the institution will not only promote excellence as a general policy, but also will make affirmative efforts to encourage and support excellence. ${ }^{91}$

\section{Research on Law and Justice}

The law schools in India need to construct a sound institutional foundation on the basis of which the intellectual and scholarly abilities of its legal scholars can be actively promoted. Law is a dynamic discipline and it is necessary that laws and their interpretation change with time and confront the challenges posed by social, economic, and

86. NAT'L KNOWLEDGE COMM'N, Gov'T OF INDLA, supra note 5, at 73.

87. See C. Raj Kumar, Op-Ed., Legal Education and Global Philanthropy, THE HINDU (India), Dec. 31, 2007, http://www.hindu.com/2007/12/31/stories/2007123153941100.htm.

88. Venkata Susmita Biswas, Chronicling Mediocrity in Law Schools, NEw INDIAN ExPRESS, Sept. 3, 2012, http://newindianexpress.com/education/edex/article599042.ece.

89. NAT'L KNOWLEDGE COMM'N, Gov'T OF INDIA, supra note 5, at 111.

90. Grove, supra note 48 (noting that the problem of underpayment in the field of academia discourages the "brightest and best" from entering the higher education sector).

91. NAT'L KNOWLEDGE COMM'N, Gov'T OF INDIA, supra note 5, at 75 (noting the need for incentives other than salary to be examined to attract talent to academia). 
political transformations in the country. Thus, the role of law schools in India is paramount in forging these changing understandings. ${ }^{92}$ Research in law should pave the way for developing greater clarity in the law and its interpretation. For example, in the United States, legal academics help to shape the United States Code and its interpretation through their research and publication. ${ }^{93}$ Similarly, in 2011, the Chief Justice of India released a Restatement of Indian Law in three subjects: Legislative Privilege, Contempt of Court, and Public Interest Litigation, drafted with the contribution of judges and advocates, as well as legal academics. ${ }^{94}$ These are some illustrative models that can be examined by the law schools in India and developed and implemented accordingly. Indian society is facing deeply institutionalized problems relating to the administration of justice because of extraordinary delays in justice delivery ${ }^{95}$ and also because of problems like poverty, corruption, favoritism, and nepotism..$^{96}$

The law schools in India should engage in the task of conducting and supporting various research projects and investigating in law and related fields. The law schools should adopt an interdisciplinary approach to law, bringing thematic, empirical, and applied research to the key issues concerning law and justice. ${ }^{97}$ This process of investigation is vital for promoting good governance and for enabling a thorough examination of the role of law and justice in Indian society. Also, the law schools should further encourage research in new and developing fields of law that take into account the impact of globalization, the advancement of science and technology, and indeed, the changing

92. See generally Elizabeth Chambliss, Two Questions for Law Schools About the Future Boundaries of the Legal Profession, 36 J. LEGAL PROF. 329 (2012) (proposing a framework for innovation in legal education by focusing legal education while developing pre- and post- J.D. training to allow for "flexible entry and exit points at various stages of specialization" within legal education).

93. See About the Office and the United States Code, OFF. OF THE L. REvision Couns., http://uscode.house.gov/about/info.shtml (last visited Oct. 10, 2012) (describing the role of the Office of the Law Revision Counsel in drafting the United States Code).

94. J. Venkatesan, Supreme Court Restates Legislation on Key Subjects, THE HINDU, Oct. 8, 2011, http://www.thehindu.com/news/national/article2518373.ece.

95. Vandana Ajay Kumar, Judicial Delays in India: Causes \& Remedies, 4 J.L. Pol'Y \& Globalization 16, 16 (2012), available at http://www.iiste.org/Journals/index.php/ JLPG/article/view/2069/2048.

96. See V. Eshwar Anand, Corruption in Judiciary: Time for Action, TRIBUNE (Chandigarh, India), Dec. 3, 2010, http://www.tribuneindia.com/2010/20101203/edit.htm\#6.

97. To see how clinical legal education in law schools can promote social justice lawyering, see Margaret Martin Barry et al., Teaching Social Justice Lawyering: Systematically Including Community Legal Education in Law School Clinics, 18 CLINICAL L. REV. 401 (2012); and Susan L. Brooks, Meeting The Professional Identity Challenge in Legal Education Through a Relationship-Centered Experiential Curriculum, 41 U. BALT. L. REV. 395 (2012). 
nature of the legal profession. Interestingly, due to all these developments, the role of the judiciary in India is also changing and this must be taken into consideration when examining good governance..$^{98}$

The law schools' research should focus on evaluating this role and its impact on law and justice in Indian society. This is possible only if the law schools develop stronger relationships with the legal and wider intellectual community in India and abroad. ${ }^{99}$ To start with, law schools should identify similar institutions in India in related disciplines and work to build useful partnerships and exchange programs. In due course, this may lead to legal scholars of a university working on joint projects that cut across various disciplines such as law, sociology, political science, public administration, economics, and anthropology. ${ }^{100}$

The law schools need to take as their anchor the principles on which law is consecrated and justice delivered in India. Law's fundamental desire is to reinforce the Indian citizenry's faith and trust in the justice system. This work of the law schools can only be partially performed through the intellectual and academic pursuits of scholars. For public involvement to be encouraged and for academics to descend from their ivory towers, it is important that legal scholarship becomes rigorously engaged with society's continued transformations and discontents. As such projects flourish, Indian society's faith in the foundations of the rule of law and democracy can be restored.

\section{Rule of Law and Legal Education}

The foundations of the rule of law in India can be traced back to ancient times. ${ }^{101}$ In more recent times, common law traditions, the Constitution of India, and the pursuant role of the judiciary have

\footnotetext{
98. See Kantrao P. Pole (Naik), Judicial Activism \& the Changing Nature of the State in Globalization, 1 INT'L RES. J. 49, 49 (2010), http://www.ssmrae.com/ admin/images/80ec6af32106f5b0d0562f2db97d4ace.pdf (discussing the activist stand taken by the Indian Supreme Court in wake of the increasing privatization in India).

99. See, e.g., Cooper, supra note 63 , at 348 (discussing how global collaborations in legal educations can help in transitioning China towards a fair criminal justice system through, inter alia, improvements in quality and consistency of legal education).

100. See generally Ron Harris, Legal.Scholars, Economists, and the Interdisciplinary Study Of Institutions, 96 CORNELL L. REv. 789 (2011) (discussing the impact of interdisciplinary cooperation on legal discourse).

101. Rule of Law Is Ancient Indian Tradition, Hindustan Times, Mar. 5, 2006, http://www.hindustantimes.com/News-Feed/NM7/Rule-of-law-is-ancient-Indiantradition/Article1-71747.aspx. Former Supreme Court of India Justice B.N. Srikrishna referred to ancient texts and observed that the rule of law in India is not an imported concept.
} 
contributed to the development of rule of law. ${ }^{102}$ But when it comes to enforcement, there is much to be desired. Blatant violation of law is a reality in India, and hence there is a need to seriously work toward establishing a law-abiding society. 103 "The rule of law is protected only when there is a fairly predicable legal system that responds to needs and problems in a fair, non-discriminatory, and effective manner, and there is access to justice."104 The lack of legal enforcement undermines the very basis of democracy in India, and the time has come to tackle it in a systematic manner. While there is no single solution, it is important to recognize that initiatives should focus on inculcating a respect for law among the Indian citizenry. This means all legal, institutional, judicial, and constitutional measures to ensure the rule of law should be oriented towards inculcating a respect for law on the basis of the belief that it will be enforced equally and fairly.

Legal education has an important role to play in the establishment of a law-abiding society. Excellence in legal education and research is extremely important because it will help shape the quality of the rule of law. ${ }^{105}$ Some issues within the relationship between legal education and research deserve serious attention.

To begin, law schools in India ought to create greater opportunities for faculty and students to undertake original and serious research on issues relating to law and justice that affect Indian society. They should create a proper research environment that enables scholars to identify issues that serve as an impediment to the efficient and effective administration of justice. ${ }^{106}$ This would be possible through a comprehensive examination of the legal framework and justice delivery mechanisms in India and could result in meaningful recommendations suitable to the social and economic needs of the people. Comparative research and development of institutional partnerships, both within the country and also with developing and developed countries, would go a long way toward acquiring a broad understanding of the experiences of

102. See Upendra Baxi, The Rule of Law in India, SuR: INT'L J. HuM. RTS., no. 6, 2007, at 7, 17-18; H.M. SEERVAI, The Supreme Court of India and the Shadow of Dicey, in THE POSITION OF THE JUDICIARY UNDER THE CONSTITUTION OF INDIA 78, 83-96 (1970).

103. Rule of Law Index: India Ranks Poor 78th in 97 Nations, REDIFF NEWS (Nov. 28, 2012), http://www.rediff.com/news/slide-show/slide-show-1-rule-of-law-index-india-rankspoor-78th-in-97-nations/20121128.htm.

104. C. Raj Kumar, Corruption as a Human Rights Issue in South Asia: Law, Development and Governance, MONASH U.: CASTAN CENTRE (Dec. 2006), http://www.law.monash.edu.au/castancentre/events/2006/conf-06-kumar-paper.html.

105. See Charles E. Tucker, Jr., Cabbages and Kings: Bridging the Gap for More Effective Capacity-Building, 33 U. PA. J. INT'L L. 1169, 1192-93 (2012) (arguing that more focus needs to be placed on developing the rule of law at the local level).

106. NAT'L KNOWLEDGE COMM'N, GOV'T OF INDIA, supra note 5, at 80-81. 
other jurisdictions and toward reforming the administration of justice and law in India. Experiences from other jurisdictions should be thoroughly examined by legal scholars and independently assessed with regard to their suitability and appropriateness to Indian conditions. ${ }^{107}$ Reforming the administration of justice and of law in India is a tall order. It will involve a concerted effort by various actors, including the members of the Bar and the bench, parliamentarians, members of civil society at large, academics, and many others. Moreover, legal scholars can help by conducting rigorous research and by analyzing the various structural problems of our civil and criminal justice systems from various angles and their implications for the rule of law in India.

Next, law schools must promote the principle of a rule of law society. ${ }^{108}$ This ought to be done not only by imparting high quality legal education through cutting-edge research on numerous issues that affect law and society, but also by devoting time and attention to the question of what kind of society India ought to develop and what ought to be the role of lawyers and law academics in that society. This role of law schools is very important, and they are quite suited to perform it if they can develop a sound institutional foundation that promotes the intellectual and scholarly abilities of legal scholars. The law and its interpretation need to change with time so that they can confront the challenges that are posed by the social, economic, and political transformations in society. ${ }^{109}$ Thus, the role of law schools assumes significance, particularly in relation to the social expectations generated because of the nature of universities as institutions of quality research and higher learning. ${ }^{110}$

Indian society is facing deeply institutionalized problems relating to the administration of justice because of extraordinary delays in justice delivery and problems like governance crises, poverty, and corruption. ${ }^{111}$ "As a consequence, the distance between the 'law in books' and the 'law

107. See Krishnan, supra note 53, at 488 (discussing the choice by developers of law schools in India not to copy foreign law school models so as to retain Indian character).

108. See Theodore A. Feitshans, The Importance of a Legal Education, 16 DRAKE J. AGRIC. L. 1, 3-4 (2011) (discussing the failure of the American education system to educate students on rule of law principles).

109. David R. Barnhizer, The Purposes and Methods of American Legal Education, $36 \mathrm{~J}$. LEGAL PRoF. 1, 27-29 (2011).

110. See C. Raj Kumar, Towards a Broader Vision: Lawyers Must Continue to be at the Forefront of Social Change in India, CAREERS 360 (May 1, 2009), http://www.careers360.com/news/2978-Towards-a-broader-vision (arguing that legal education in India should focus on becoming more global and developing lawyers who are committed to public service).

111. See, e.g., Marc Galanter \& Jayanth K. Krishnan, "Bread for the Poor": Access to Justice and the Rights of the Needy in India, 55 HASTINGS L.J. 789 (2004) (reporting the results of a study on India's court system and the challenges the system continues to face). 
in reality' is widening." 112 If Indian society is to confront this challenge and establish good governance based only on the rule of law, it is essential that law schools play a more active and responsible role. The future development of legal education in India should encourage scholars to develop research inputs on the various problem areas of law for better understanding of the institutions engaged in law reform.

In addition, in order to have a direct impact on the Indian citizenry, the promotion of increased societal knowledge of law and administration of justice should be the main focus of law school activities. "It is true that the Indian judiciary has been playing this role for a long time, but the role of academic institutions such as law schools is unique and distinctive."113 Law schools should focus on advancing the foundational principles on which law is based and justice is done in India, and which are necessary for reinforcing the faith and trust of Indian citizenry in law and the justice system. ${ }^{114}$ This work can only be partially performed through the intellectual and academic pursuits of scholars. But, for public scholarship to be encouraged, it is important that legal scholarship moves toward attempts at social transformation and recognizes that the most important function of law is to ensure justice. 115 "If this function is duly performed, society can rest assured that the numerous individual instances of injustice resulting in victimisation will not in course of time result in greater threats to the foundations of the rule of law and democracy over time."116

\section{Academic Freedom in Education}

Higher education in India is in the process of transition in the face of globalization. Some of the important organizations involved in responding to the challenges of developing a knowledge economy and seeking this transition in higher education are the University Grants Commission, the Union Ministry of Human Resource Development, the

112. C. Raj Kumar, Rule of Law and Legal Education, THE HINDU (July. 4, 2006), http://hindu.com/2006/07/04/stories/2006070403320800.htm.

113. Id.

114. See Karen Tokarz \& V. Nagaraj, Advancing Social Justice Through ADR and Clinical Legal Education in India, South Africa, and the United States, in THE GLOBAL CliniCal Movement: EduCating LaWYers For Social Justice 253, 256-58 (Frank S. Bloch ed., 2011) (discussing how alternative dispute resolution clinics in law schools can help develop fundamental legal values).

115. See Bloch \& Prasad, supra note 1 (discussing how clinical education in India can find a balance between promoting social justice and developing professional skills).

116. Kumar, supra note 112. 
Planning Commission, and the National Knowledge Commission. ${ }^{117}$ Each of these organizations has its own perspective on what ought to be the future of higher education.

While there is need for consensus building and closer interaction among these organizations, the importance of promoting academic freedom should also be recognized. ${ }^{118}$ Given the challenges of privatization, academic freedom should be emphasized as a core component of ensuring higher academic standards and developing a curriculum that will meet the needs of the future. ${ }^{119}$

Specifically, the concept of academic freedom should be further examined in the light of globalization and the new challenges posed to higher education. ${ }^{120}$ There is a need for a public debate on the inherently difficult issue of how academic freedom in Indian universities can be balanced with an equally important value of ensuring transparency and accountability within public and private institutions. ${ }^{121}$ The question of accountability becomes critical in the context of growing commercialization of education, which has also undermined academic freedom. ${ }^{122}$ Promoting greater understanding of academic freedom has significant bearing on the purpose of higher education. ${ }^{123}$ It will also have an impact on determining all policies relating to higher education, including curriculum development, program administration, faculty recruitment, teaching pedagogy, assessment regimes, ${ }^{124}$ and professional engagement of educational institutions. ${ }^{125}$

117. See generally Kareena Bhatia \& Manoj Kumar Dash, National Knowledge Commission - A Step Towards India's Higher Education Reforms on India's Higher Education, INT'L RES. J. FIN. \& ECON., Oct. 2010 (discussing the substance and impact of the National Knowledge Commission's educational reform recommendations).

118. See generally Steve Sheppard, Academic Freedom: A Prologue, 65 ARK. L. REV. 177

(2012) (discussing the historical development of academic freedom in America).

119. For a brief discussion on academic freedom, see $i d$.

120. For a discussion on the meaning of "academic freedom" see Frederick Schauer, The

Permutations of Academic Freedom, 65 ARK. L. REV. 193 (2012).

121. See Ruth Jonathan, Council on Higher Educ., ACAdemic Freedom, INSTITUTIONAL AUTONOMY AND PUBLIC ACCOUNTABILITY IN HIGHER EDUCATION: A FRAMEWORK FOR ANALYSIS OF THE 'STATE-SECTOR' RELATIONSHIP IN A DEMOCRATIC SOUTH AFrICA (CHE HEIAAF Ser. No. 1, Nov. 2006), available at http://www.che.ac.za/ documents/d000138/CHE_HEIAAF_Jonathan_Nov2006.pdf.

122. See generally Julia B. Glazer \& Michael J. Tuteur, TenuRE Decisions and ACADEMIC FREEDOM ch. 2 (Supp. 2012) (discussing the development of tenure rights as they relate to academic freedom).

123. Stuart Macintyre, The Poor Relation: A History of Social Sciences in AUSTRALIA 334-35 (2010).

124. See Jeff Todd, State University v. State Government: Applying Academic Freedom to Curriculum, Pedagogy, \& Assessment, 33 J.C. \& U.L. 387 (2007) (examining the interplay 
In all these matters, policies should evolve with the changes in the landscape of higher education. ${ }^{126}$ While the legal and institutional framework for protecting the freedom of speech and expression in India is sound and the independent judiciary can enforce fundamental rights, there are certain aspects of political culture, ${ }^{127}$ religious intolerance, ${ }^{128}$ and cultural dogmatism that pose challenges to the protection of academic freedom. ${ }^{129}$

Protecting academic freedom also ought to be part of the social responsibility of both individuals and institutions. ${ }^{130}$ There are a variety of issues relating to educational policy and governance of educational institutions in which the state and its instrumentalities need to play a legitimate role. ${ }^{131}$ But this role should be judiciously balanced with the equally important responsibility of the state to protect the academic freedom of educational institutions. ${ }^{132}$

between state universities and government entities on issues of academic freedom and the impact this relationship has on curriculum, pedagogy, and assessment policies).

125. See Jordan J. Titus, Pedagogy on Trial: When Academic Freedom and Education Consumerism Collide, 38 J.C. \& U.L. 107 (2011) (discussing how the corporatization of universities and the increase in student input on the quality of education have led to a decline in faculty autonomy).

126. For an account of development of academic freedom in the United States see Richard Hofstadter \& Walter P. METzGer, The Development of ACADEMic Freedom IN THE UNITED STATES (1955).

127. See generally Nathan Harden, Academic Freedom Requires Political Freedom, INT'L BuS. TMES, Apr. 4, 2012, http:/www.ibtimes.co.uk/articles/324107/20120404/nypdmuslim-surveillance-spying-education-students.htm (examining how 9/11 has shifted the balance between national security interests and academic freedom in the United States).

128. See generally Kent Greenawalt, Religious Law Schools: Tension Between Conscience and Academic Freedom, 59 J. LEGAL EDUC. 131 (2009) (discussing how religious law schools deal with issues of academic freedom amongst their faculty while trying to maintain their religious mission).

129. See, e.g,, Sudha Ramachandran, Ramayana Row Divides India, AsIA TIMEs (Nov. 10, 2011) http://www.atimes.com/atimes/South_Asia/MK10Df01.html (discussing the removal of retellings of classic Indian tales from universities because of concerns about their portrayal of cultural figures); Ritika Chopra, Academicians Vow to Fight for Academic Freedom, INDIA TODAY (May 15, 2012), http://indiatoday.intoday.in/ story/cartoon-row-academicians-vow-to-fight-for-academic-freedom/1/188826.html (discussing the removal of political cartoons from textbooks by the Indian government).

130. See Nancy B. Rapoport, Academic Freedom and Academic Responsibility, 13 GREEN BAG 2D 189, 201 (2010) (stating that with academic freedom comes great responsibility).

131. See A. G. Noorani, Academic Freedom in Kashmir and Elsewhere, 42 ECON. \& POL. WKLY. 3600, 3601 (2007) (arguing that students and faculty need to fight to protect academic freedom at universities).

132. For a brief account of the position of the American judiciary on academic freedom and state interference see Philip T.K. Daniel \& Scott Greytak, Requiem for Affirmative Action in Higher Education: Case Analysis Leading to a Fisher v. University of Texas at Austin, 279 EDUC. L. REP. 539, 550-51 (2012). 
The state's role and responsibility in protecting academic freedom should not be limited to discretely exercising self-restraint in its possible interventions. ${ }^{133}$ The state should also ensure that other actors, including the media, political parties, and the citizenry do not by their actions undermine academic freedom. ${ }^{134}$ Intolerance of the views and opinions held by academics and other members of society leads to a culture of self-censorship that undermines free and independent thinking. ${ }^{135}$ All stakeholders should steadfastly protect the ability of universities and other educational institutions to challenge views and opinions and to be a place for creating knowledge and developing new thinking in the university governance system. ${ }^{136}$

Furthermore, because protecting academic freedom is so important, a case can be made for recognizing it as part of the national and international human rights framework. ${ }^{137}$ However, constitutional guarantees cannot ensure that academic freedom is protected unless they succeed in engaging the democratic processes-an empowering function that should be the goal of constitutionalism. ${ }^{138}$ To ensure that academic freedom is protected, democratic institutions in India must remain independent. ${ }^{139}$ The fact that many countries, in their efforts to counter terrorism, have also undermined academic freedom by invoking

133. See Judith Areen, Government as Educator: A New Understanding of First Amendment Protection of Academic Freedom and Governance, 97 Geo. L.J. 945, 988-99 (2009) (arguing that the government should have different levels of commitment to the protection of academic freedom depending on the role it is playing).

134. See Neal H. Hutchens, A Confused Concern of the First Amendment: The Uncertain Status of Constitutional Protection for Individual Academic Freedom, 36 J.C. \& U.L. 145, 175 (2009) (arguing that increased scrutiny of scholars by political leaders and media can also challenge individual academic freedom).

135. See Malika Rebai Maamri, Academic Freedom in Principle and Practice: The Case of Algeria, 3 AAUP J. OF ACAD. FREEDOM 19 (2012), available at http://www.academicfreedomjournal.org/VolumeThree/Maamri.pdf (explaining that "gang stalking" by those in power leads to a perpetual culture of self-censorship because the academic community is careful not to offend those in power for fear of retaliation).

136. See generally Schauer, supra note 120 (clarifying the role that universities play in protecting academic freedom).

137. See William A. Schabas, Free Speech on Campus: Lessons from International and Comparative Law, 44 UNIV. NEW BRUNSwICK L.J. 111, 117 (1995) (arguing that free speech must be protected everywhere, but especially in the university).

138. For an argument on the importance of academic freedom as a fundamental right and the cases in which it can be restricted by courts in the United States see generally David Fox, Turning up the Heat on Science: A New Threat to Academic Freedom, 43 U. TOL. L. REV. 173 (2011) (suggesting the Court should reaffirm its earlier holdings on academic freedom and make it a fundamental right).

139. See Noorani, supra note 131 (explaining that there is a need for a statute that codifies the rights of students and teachers with respect to freedom of speech). 
provisions of national security or antiterrorism legislation demonstrates the need for independent democratic institutions. ${ }^{140}$

The formal mechanisms for protecting academic freedom through the constitutional apparatus, institutional guarantees, and their enforcement by the judiciary can fail, particularly when these institutions operate under limitations. ${ }^{141}$ There should be further space provided for democratic dissent and resistance to intrusions into academic freedom. ${ }^{142}$ This space is typically addressed by liberal constitutions in both rights guarantees and democratic commitments. ${ }^{143}$ It should be an autonomous space for academics and others to take upon themselves the task of promoting debates as public intellectuals. ${ }^{144}$

Resistance from academics can actually serve as a check on the different branches of government to ensure that rights are duly protected and that there is a greater sense of transparency and accountability in governance. ${ }^{145}$ There is also need for the relevant official bodies to address many of these challenges in a systematic, analytical, dispassionate, and easily understandable manner.

Consider, moreover, how in the United States, academic freedom is generally taken as the notion defined by the 1940 Statement of Principles on Academic Freedom and Tenure, jointly authored by the American Association of University Professors and the Association of American Colleges, now known as the Association of American Colleges and Universities. ${ }^{146}$ One of the earliest initiatives to protect academic

140. See, e.g., R. Kenton Bird \& Elizabeth Barker Brandt, Academic Freedom and 9/11: How the War on Terrorism Threatens Free Speech on Campus, 7 COMM. L. \& POL'Y 431, 447-48 (2002) (discussing previous instances in which national crises have led to infringements of academic freedom).

141. See Suzanne R. Houle, Is Academic Freedom in Modern America on its Last Legs After Garcetti v. Ceballos?, 40 CAP. U. L. REV. 265, 265-66 (2012) (highlighting the "current bright-line rule pertaining to public employees' free speech right as pronounced in Garcetti, where the Supreme Court of the United States held that public speech made pursuant to official duties receives no First Amendment protection").

142. See generally ROBERT C. POST, DEMOCRACY, EXPERTISE, AND ACADEMIC FREEDOM: A FiRST AMENDMENT JURISPRUdENCE FOR THE MODERN STATE (2012) (analyzing the First Amendment and its relationship with disciplinary knowledge).

143. See generally id.

144. Marcia M. Boumil et al., Pharmaceutical Speakers' Bureaus, Academic Freedom, and the Management of Promotional Speaking at Academic Medical Centers, 40 J.L. MED. \& ETHICS 311, 316 (2012).

145. See Catherine Chaput, Academic Freedom, Professional Transparency, and Intellectualism in the Era of Globalization, 26 J. ADVANCED COMPOSITION 326, 331 (2006) (explaining that pressure from society for "transparency from centers of power will lead the way to a more open and just world").

146. 1940 Statement of Principles on ACAdemic Freedom ANd Tenure 3-4 (10th ed. 2006) (defining academic freedom); see generally HOFSTADTER \& METZGER, supra note 126 (providing a historical account of academic freedom in the United States). 
freedom was the international conference convened by the United Nations Educational, Scientific, and Cultural Organization (UNESCO) in 1950, in Nice, where the universities of the world "articulated three interdependent principles for which every university should stand:"147 first, "the right to pursue knowledge for its own sake and to follow wherever the search" for truth may lead; second, "the tolerance of divergent opinion and freedom from political interference;" and third, "the obligation as social institutions to promote, through teaching and research, the principles of freedom and justice, of human dignity and solidarity, and to develop mutually material and moral aid on an international level." 148

In January 2005, the first Global Colloquium of University Presidents met at Columbia University, in New York, ${ }^{149}$ to respond to the United Nations Secretary-General's request for greater involvement of the global academic community in exploring international public policy concerns. ${ }^{150}$ The inaugural meeting gathered more than forty university leaders and professors. ${ }^{151}$ The main theme of discussion among them was academic freedom. ${ }^{152}$ Noting the importance of academic freedom, the report of the colloquium said:

Academic freedom benefits society in two fundamental ways. It benefits society directly, and usually immediately, through the impacts and benefits of applied knowledge, the training of skilled professionals, and the education of future leaders and citizens. It benefits society indirectly and usually over longer periods of time, through the creation, preservation, and

147. Paul Maylam \& Peter Vale, Submission to The Council on Higher EDUCATION'S TASK TEAM ON SOUTH AFRICAN GOVERNMENT INVOLVEMENT AND REGULATION OF HIGHER EDUCATION, INSTITUTIONAL AUTONOMY AND ACADEMIC FREEDOM (2005), available at http://www.che.ac.za/documents/d000173/submissions/05_RU_5Oct05.pdf.

148. See generally ERIC BARENDT, ACADEMIC FREEDOM AND THE LAW: A COMPARATIVE STUDY (2010) (providing analysis of the law and how it relates to academic freedom in the United Kingdom, Germany, and the United States).

149. Press Release, Columbia Univ., Columbia Univ. Hosts First Global Colloquium of Univ. Presidents (Jan. 18, 2005), available at http://news.columbia.edu/pressroom/1289.

150. Global Colloquium of University Presidents, UNIV. PA., http://www.upenn.edu/president/global-colloquium-university-presidents (last visited Aug. 23, 2012) (stating this meeting was of interest to the Secretary-General in regards to time).

151. Id.

152. Id. 
transmission of knowledge and understanding for its own sake, irrespective of immediate applications. ${ }^{153}$

Academic freedom is central to the future of India's higher education system as it strives to develop a knowledge economy based on the need to promote intellectual capital and to develop institutions of excellence comparable to the best elsewhere in the world. ${ }^{154}$ Indian legal educational institutions, in particular, can and should take cues from these comparative examples.

\section{CONCLUSION: THE WAY FORWARD}

If the law schools in India are to provide institutional leadership in the fields of teaching, research, and learning, it is necessary for them to rethink the nature of legal education. The system of legal education in India is facing significant challenges. ${ }^{155}$ While the national law schools have flourished over the years and have provided new opportunities to create institutions of excellence, ${ }^{156}$ there is still need to continuously assess and evaluate our law schools in the light of the challenges to the rule of law.

Some of the challenges facing legal education include maintaining good quality law schools that can produce good lawyers, teachers, and law professionals; ${ }^{157}$ expanding the presence of good caliber law teachers who can motivate the students and impart good legal education, including clinical legal education; motivating law students to choose various career paths within the legal profession or to opt for legal academia; and sustaining good legal talent within India, which includes persuading lawyers who are practicing or working abroad to return to

153. C. Raj Kumar, Academic Freedom and Higher Education, THE HINDU (Nov. 13, 2007), http://www.thehindu.com/2007/11/13/stories/2007111352170800.htm.

154. See Philip G. Altbach, Academic Freedom: A Realistic Appraisal, UnIv. WorLD NEws (Sept. 20, 2009) http://www.universityworldnews.com/article.php?story= 20090917184023431 (explaining that evidence seems to show that academic freedom is a necessary condition for high quality universities).

155. Justice S.P. Mehrotra, Re-Inventing Legal Education: Challenges \& Opportunities, INST. OF JUD. TRAINING \& RES., http://www.ijtr.nic.in/webjournal/6.htm (last visited Aug. 23, 2012).

156. See N.R. Madhava Menon, Harvard LaW School Program on the Legal PROFESSION: THE TRANSFORMATION OF INDIAN LEGAL EDUCATION 8 (2012).

157. See John Flood, Legal Education in the Global Context: Challenges from Globalization, Technology and Changes in Government Regulation 25 (Univ. of Westminster Sch. of L., Working Paper No. 11-16), available at http://blenderlaw.umlaw.net/wp-content/uploads/2010/09/Global_Legal_Ed.pdf (explaining that quality in Indian legal education is an omnipresent problem). 
India to pursue similar work. ${ }^{158}$ These are all important issues and there are no simple answers. Law scholars in India should act as facilitators in conducting discussions on these matters among the law schools of the country and interested members of the Bar and the bench.

In fact, the most important objective of legal education ought to be promoting excellence in both teaching and research. But these objectives ought to be fulfilled bearing in mind their relevance to and linkages with establishing a rule-of-law-friendly society. The present state of the civil and criminal justice systems in India poses numerous challenges and is far from providing the much-needed faith and respect for law and legal institutions. While every institution has an important role to play in ensuring the rule of law, law schools have so far not been seen as leaders in this regard. It is time for law schools and legal education discourse in India to embrace this responsibility, lest the faith of the students and the faculty in the role of law and its impact on justice be lost forever.

Recently, while inaugurating the Conference of National Consultation for Second Generation Reforms in Legal Education, Dr. Manmohan Singh, the Prime Minister of India, said the following:

Over half a century ago, the then President of India, Dr. Radhakrishnan stated-and he himself was a great teacher-lamented that 'our colleges of law do not hold a place of high esteem either at home or abroad, nor has law become an area of profound scholarship and enlightened research'. It's no doubt we have traveled a long distance since that time. But we must admit and have to ask honestly ourselves whether we have significantly altered the landscape of our legal education system. We do have a small number of dynamic and outstanding law schools, but I am afraid they remain islands of excellence amidst a sea of institutionalized mediocrity. We are not even marginally nearer to profound scholarship and enlightened research in law. As we and we [sic] must introspect honestly, we must sadly accept that Dr [sic] Radhakrishnan's powerful yet poignant words may not be amenable to any radical restatement even today. ${ }^{159}$

158. See generally Krishnamurthy, supra note 60 (explaining some of the actions that need to be followed to improve legal education in India).

159. On May 2, 2010, Dr. Manmohan Singh, the Prime Minister of India, inaugurated the Conference of National Consultation for Second Generation Reforms in Legal Education. See 
People who were trained in law played an important role in India's freedom struggle, ${ }^{160}$ and later made the weightiest contribution to the governance process in the early years of nation building. ${ }^{161}$ While different disciplines of study equip people with different kinds of expertise that assist in governance, lawyers can and should understand the need for the protection of the rule of law and the assurance of access to justice and fairness, due to the nature and content of legal education. The Indian freedom movement indeed involved some phenomenally talented lawyers, whose contribution to the freedom struggle and the never-ending pursuit of achieving justice was truly remarkable. "The key figures of the freedom struggle who were trained lawyers included Mohandas Karamchand Gandhi, Motilal Nehru, Jawaharlal Nehru, Sardar Vallabhai Patel, Rajendra Prasad, Bhimrao Ramji Ambedkar, and many other distinguished and committed persons." 162

Legal education should place the highest priority on public service. The notion of true public service moves beyond ideological barriers to embrace the widest range of possibilities for lawyers to contribute to the betterment of society. In most developed countries, lawyers and law firms play an important role in contributing to social issues, either in the form of legal aid work that they undertake as a part of litigation, or in the form of pro bono work, where they assist less well-off citizens at no charge, particularly in cases of important social resonance. There are a number of social issues that India's lawyers also contribute to, ${ }^{163}$ but this needs to be significantly enhanced. Legal education in India ought to develop a sense of public service from the outset that will instill in our lawyers a willingness to make commitments to contribute to society. ${ }^{164}$ Globalization and the new employment opportunities offered by law firms and corporations have undoubtedly created huge financial incentives for Indian lawyers. However, our law schools and universities have to work toward creating a conducive environment within the educational institutions that will promote and encourage lawyers'

Second Generation Reforms in Legal Education, INDIA CURRENT AFFAIRS (May 2, 2010), http://indiacurrentaffairs.org/second-generation-reforms-in-legal-education/.

160. See Keshav Dayal, Famous lawyers of Freedom Struggle and Trials of FREEDOM FTGHTERS (2010).

161. See The Role of Lawyers is Not Confined to Courts: PM, REDIFF News (May 17, 2010) [hereinafter Role of Lawyers], http://news.rediff.com/column/2010/may/17/role-oflawyers-is-not-confined-to-courts-says-pm.htm.

162. C. Raj Kumar, Towards a Broader Vision, CAREERS 360 (May 1, 2009), http://www.careers360.com/news/2978-Towards-a-broader-vision.

163. Role of Lawyers, supra note 161.

164. See Second Generation Reforms in Legal Education, supra note 159 (suggesting the legal education system should be more sensitive to the needs of the underprivileged of the community). 
sensibility toward public service. Legal education should embrace within its fold the concept of nation building so that the lawyers we produce have a broader framework and vision to contribute to society through public service. ${ }^{165}$

165. See Reena N. Glazer, Revisiting the Business Case for Law Firm Pro Bono, 51 S. TEX. L. REV. 563, 565 (2010) (explaining pro bono supporters must identify the aspects of pro bono work that yield valuable benefits for the attorneys, law firms, pro bono clients served, and communities). 